\title{
Renal metastasis after esophagectomy of esophageal squamous cell carcinoma: a case report and literature review
}

Yan Sun ${ }^{1,2}$ Xinmin $Y u^{1,2^{*}}$ and Yiping Zhang ${ }^{1,2^{*}}$

\begin{abstract}
Solitary metastatic renal tumors are rarely encountered. We report the case of a 63-year-old man who developed a solitary renal metastasis after undergoing an esophagectomy for esophageal squamous cell carcinoma and subsequent nephrectomy of the right kidney.
\end{abstract}

Keywords: Kidney, Metastasis, Esophageal carcinoma

\section{Background}

Esophageal cancer (EC) is one of the top six leading causes of death from cancer; it exhibits a strikingly uneven geographical distribution, resulting in focal endemic high-incidence areas in several countries [1]. Although considerable advances in diagnosis, surgical techniques and chemoradiotherapy have been made, EC still remains one of the most lethal cancers and most patients die from its recurrence or metastasis, with a fiveyear survival rate as low as $16 \%$ in 2009 in the United States [2]. In China, the situation is even worse [3]. Although $50 \%$ to $70 \%$ of patients can be treated surgically with a chance of cure, half of the patients suffer from local recurrences or metastasis after complete resection. The most common sites of metastasis are the liver, lung, bone and adrenal glands [4]. Metastases of esophageal carcinoma in the kidney are considered to be extremely rare, especially a unilateral renal metastasis [5]. There are few cases that have been reported of solitary renal metastasis of an esophageal carcinoma [6-12]. Herein, a case of solitary, unilateral renal metastasis in a patient after esophagectomy is reported (Table 1 ).

\footnotetext{
* Correspondence: zjch1971@163.com; yipingzhang@yahoo.cn

'Department of Chemotherapy, Zhejiang Cancer Hospital, 38 Guangji Road, 310022 Hangzhou, P.R. of China

${ }^{2}$ Key Laboratory Diagnosis and Treatment Technology on Thoracic Oncology, Zhejiang, ProvinceHangzhou 310022, China

Full list of author information is available at the end of the article
}

\section{Case report}

A 63-year-old man was admitted to our hospital for an evaluation of progressive dysphagia for about one month. A barium esophagogram demonstrated a mass in the low esophagus. Chest and abdominal computed tomography (CT) showed no abnormalities in other organs. The patient underwent esophagectomy with stage P-T2N0M0 in December 2008. Pathological examination of the specimen revealed squamous cell carcinoma with moderate differentiation. The patient was referred again for osphyalgia nine months after the esophagectomy, with no hematuria or any other urinary symptoms. Abdominal $\mathrm{CT}$ and ultrasound examination showed a mass measuring $6.5 \times 1.5 \mathrm{~cm}$ in the right kidney (Figure 1a). No metastatic lesions were evident at other sites. A right nephrectomy was performed. Pathological examination of the specimen led to a diagnosis of squamous cell carcinoma (Figure 1b).

The patient died of whole body metastasis and respiratory failure in December 2009.

\section{Discussion}

The incidence of distant metastases from a resectable esophageal carcinoma has been reported as approximately $20 \%$ to $30 \%$ [13]. Several reports demonstrated that the most common site of spread is the abdominal lymph nodes, followed by the liver, lung and bone. Autopsy studies have shown that about $12 \%$ of patients dying of cancer have renal metastases, making the kidney a common metastatic site [14]. In contrast to autopsy findings, 
Table 1 Reported cases of metastatic renal tumor of esophageal cancer

\begin{tabular}{lllllll}
\hline Case & Sex & Age & Side & Histology & Treatment & OS after renal metastasis (month) \\
\hline $1[5]$ & Male & 64 & Left & SCC & Nephrectomy & Unknown \\
$2[10]$ & Male & 65 & Right & SCC & Nephrectomy + Chemotherapy & $6+$ \\
$3[6]$ & Male & 57 & Right & SCC & Nephrectomy & $3+$ \\
$4[6]$ & Male & 57 & Right & SCC & Nephrectomy & 2 \\
$5[7]$ & Male & 61 & Left & SCC & Nephrectomy + Chemotherapy & 2 \\
$6[8]$ & Male & 74 & Right & SCC & Partial nephrectomy & Unknown \\
$7[9]$ & Male & 50 & Right & SCC & Nephrectomy + radiotherapy & 4 \\
$8[11]$ & Male & 62 & Left & SCC & Chemotherapy + irradiation + nephrectomy & Unknown \\
$9[12]$ & Male & 56 & Left & Epidermoid & Nephrectomy & 6 \\
$10[14]$ & Male & 62 & Left & Epidermoid & Nephrectomy & 2 \\
\hline
\end{tabular}

OS, overall survival; SCC, squamous cell carcinoma.

clinical detection of these tumors is rare. The reason may be attributable to ignorance of such rare metastases while the patient is alive. Most patients with renal metastases are asymptomatic, despite extensive renal involvement. Hematuria and proteinuria occur in fewer than $20 \%$ of

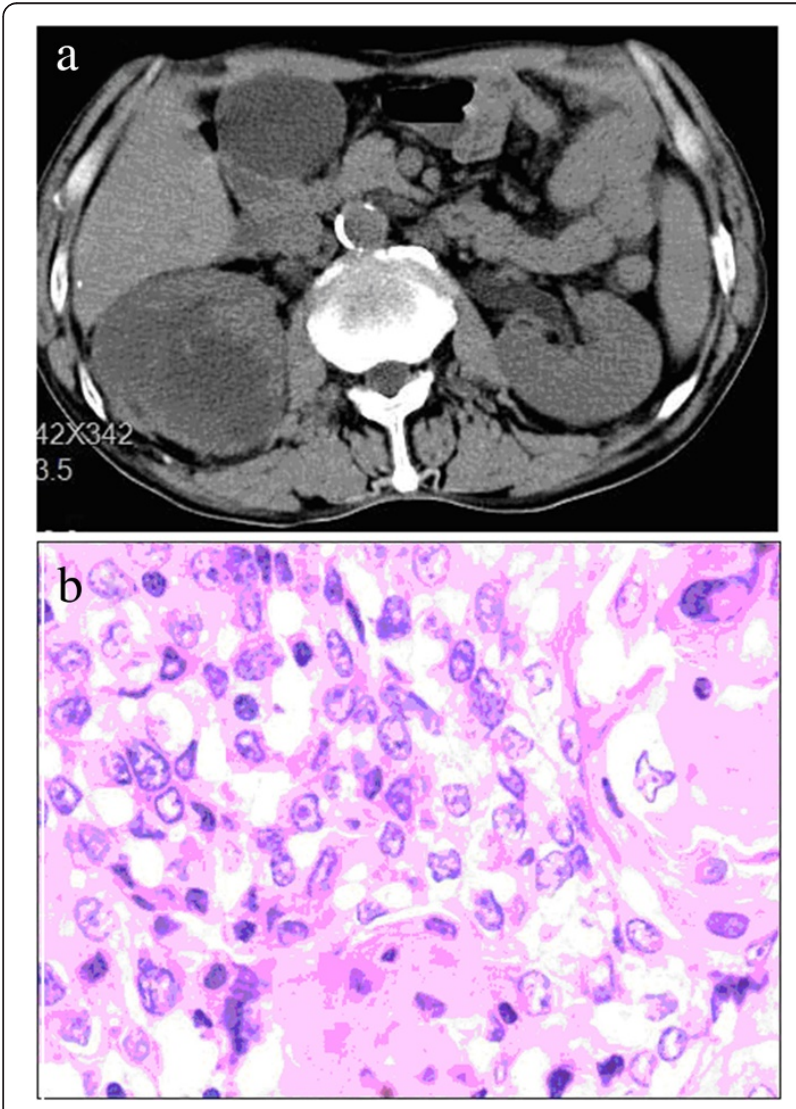

Figure 1 Abdominal CT scan and histological showing a kidney metastasis of esophagus cancer. a) Abdominal CT scan showing a mass in the right kidney. b) Histological examination revealed the same cell type as the previous esophagus cancer. (H\&E, 100). patients. Therefore, the diagnosis of renal metastases is very difficult and it is often found accidentally.

There are some differences in clinical manifestation between primary renal cell carcinoma and metastatic carcinoma. Most primary renal cell carcinomas are, on average, larger than metastatic renal tumors. Metastatic renal tumors are frequently observed in subcapsular locations. The typical pattern of renal metastases consists of multiple small nodules and almost all cases are associated with widespread non-renal metastases [15]. Moreover, unilateral, solitary renal metastasis is extremely rare. With respect to the pathology, the clear cell type is most commonly observed in primary renal cell carcinoma. However, squamous cell carcinoma has the highest occurrence among metastatic renal tumors from esophageal carcinoma.

Because of the rarity of renal metastasis of esophageal carcinoma, no conclusive treatment has been established yet according to the European Association of Urology (EAU) guidelines and National Comprehensive Cancer Network (NCCN) guidelines. Imada et al. [16] suggested that an aggressive and careful surgical approach with adequate follow-up may offer a chance of long-term survival for patients with multiple cancers. Grise et al. [12] reported that solitary metastatic renal tumor could be an indication for nephrectomy. In our case, since the tumor seemed to be a solitary renal metastasis without any other metastatic lesions, nephrectomy was performed. Pathological assessment showed a single metastatic squamous carcinoma of the same cell type as the previous esophagus cancer. The present case serves to demonstrate that careful follow up is needed for esophageal cancer patients with a cancer in another organ including rare site metastasis.

The median survival following the detection of a recurrent or metastatic esophageal carcinoma is two to ten months [17]. The treatment outcome of a recurrent disease is disappointing, and the prognosis is poor. In this 
case, the patient achieved a nine-month recurrence free survival time after esophagectomy, and recurred with a solitary metastasis mass in the right kidney. A nephrectomy was performed and the patient died of metastasis three months later.

\section{Conclusions}

In summary, a renal metastasis after anesophagectomy of esophageal carcinoma is reported. Renal metastasis should be considered whenever a mass in the kidney is identified. The prognosis is poor even when surgery is performed.

\section{Consent}

Written informed consent was obtained from the patient for the publication of this report and any accompanying images.

\section{Competing interests}

The authors declare that they have no competing interests.

\section{Authors' contributions}

$X Y$ and $Y Z$ cooperated in the conception and design of the study, and in the collection of the data; YS drafted the manuscript. All authors approved the final manuscript.

\section{Author details}

${ }^{1}$ Department of Chemotherapy, Zhejiang Cancer Hospital, 38 Guangji Road, 310022 Hangzhou, P.R. of China. ${ }^{2}$ Key Laboratory Diagnosis and Treatment Technology on Thoracic Oncology, Zhejiang province, Hangzhou 310022, China.

Received: 10 November 2013 Accepted: 2 May 2014

Published: 26 May 2014

\section{References}

1. Fisher S, Brady L: Esophagus. In Principles and Practice of Radiation Oncology. 3rd edition. Edited by Perez CA, Brady L. Philadelphia, PA Lippincott-Raven; 1998:1241-1256.

2. Jemal A, Rebecca SR, Ward E, Hao Y, Xu J, Thun MJ: Cancer statistics 2009. CA Cancer J Clin 2009, 59:225-249.

3. Yang L, Parkin DM, Li L, Chen Y: Time trends in cancer mortality in China: 1987-1999. Int J Cancer 2003, 106:771-783.

4. Quint LE, Hepburn LM, Francis IR, Whyte RI, Orringer MB: Incidence and distribution of distant metastases from newly diagnosed esophageal carcinoma. Cancer 1995, 76:1120-1125.

5. Lim DH, Im YH, Ji SH, Park BB, Oh MJ, Lee J, Park KW, Lee SH, Park JO, Kim K, Kim WS, Jung CW, Park YS, Kang WK, Lee MH, Kim K, Shim YM, Park K: Esophageal squamous cell carcinoma recurring as a solitary renal mass. Cancer Res Treat 2004, 36:271-274.

6. Miyoshi Y, Asakura T, Matsuzaki J: Metastatic renal tumor originating from esophageal cancer: report of 2 cases. Hinyokika Kiyo 1997, 43:347-350. Article in Japanese.

7. Kitami K, Masuda M, Chiba K, Kumagai H: Metastatic renal tumor originating from esophageal carcinoma: a case report. Hinyokika Kiyo 1987, 33:122-125. Article in Japanese.

8. Matsushita Y, Katoh T, Isurugi K, Obara W, Suzuki T, Tamura T, Tanji S, Fujioka T: Metastatic renal tumor originating from esophageal carcinoma: a case report. Hinyokika Kiyo 1998, 44:591-594. Article in Japanese.

9. Nagai T, Takashi M, Sakata T, Sahashi M, Simoji T, Miyake K: A case of esophageal cancer metastatic to the kidney presenting as renal pelvic cancer. Hinyokika Kiyo 1989, 35:1565-1568. Article in Japanese.

10. Ku JH, Park KH, Lee E, Heo DS, Kim HH: Solitary squamous cell carcinoma in the kidney after metachronous development of esophageal and lung cancer. Tumori 2005, 91:93-95.
11. Shimizu H, Koyama Y, Ozawa I: An esophageal cancer with a renal metastasis that was detected and resected as the only focus of recurrence. Gan No Rinsho 1990, 36:2047-2052. Article in Japanese.

12. Grise P, Botto H, Camey M: Esophageal cancer metastatic to kidney: report of 2 cases. J Urol 1987, 137:274-276.

13. Nakagawa S, Kanda T, Kosugi S, Ohashi M, Suzuki T, Hatakeyama K: Recurrence pattern of squamous cell carcinoma of the thoracic esophagus after extended radical esophagectomy with three-field lymphadenectomy. J Am CollSurg 2004, 198:205-211.

14. Pollack HM, Banner MP, Amendola MA: Other malignant neoplasms of the renal parenchyma. Semin Roentgenol 1987, 22:260-274.

15. Wagle DG, Moore RH, Murphy GP: Secondary carcinomas of the kidney. J Urol 1975, 114:30-32

16. Imada T, Sato H, Hasuo K, Nagano A: Development of synchronous bilateral lung cancers after esophagectomy for esophageal cancer: report of a case. Surg Today 1998, 28:1042-1045.

17. Mariette C, Fabre S, Balon JM, Finzi L, Triboulet JP: Factors predictive of complete resection of operable esophageal cancer: review of 746 patients. Gastroenterol Clin Biol 2002, 26:454-462.

doi:10.1186/1477-7819-12-165

Cite this article as: Sun et al: Renal metastasis after esophagectomy of esophageal squamous cell carcinoma: a case report and literature review. World Journal of Surgical Oncology 2014 12:165.

\section{Submit your next manuscript to BioMed Central and take full advantage of:}

- Convenient online submission

- Thorough peer review

- No space constraints or color figure charges

- Immediate publication on acceptance

- Inclusion in PubMed, CAS, Scopus and Google Scholar

- Research which is freely available for redistribution 